\title{
PENERAPAN PENDIDIKAN KARAKTER TERHADAP EFEKTIFITAS PENGGUNAAN KURIKULUM 2013 DALAM PERSEPEKTIF MORAL BANGSA DI SMA NURUL JANNAH NW AMPENAN
}

\author{
Fitriani', Abdul Sakban² \\ ${ }^{1}$ Pendidikan Pancasila dan Kewarganegaraan, Universitas Muhammadiyah Mataram, sakban.elfath@yahoo.co.id
}

INFO ARTIKEL
Riwayat Artikel:
Diterima: $\quad$ 12-Januari-
2018
Disetujui: 15-Maret-2018

Kata Kunci:

Pendidikan karaakter Kurikulum 13

Moral Bangsa

\begin{abstract}
ABSTRAK
Abstrak: Tujuan penelitian ini untuk mengetahui penerapan pendidikan karakter terhadap efektifitas penggunan kurikulum 2013 dalam persepektif moral bangsa dan untuk mengetahui kendala yang dihadapi guru dalam penerapan kurikulum 2013. Penelitian ini merupakan penelitian kualitatif dengan pendekatan deskriptif. Teknik pengambilan sampel dengan menggunakan snowball sampling. Informan kunci dalam penelitian ini adalah kepala sekolah, waka kurikulum, wali kelas, guru dan siswa. Data penelitian diperoleh melalui tehnik observasi, wawancara dan dokumentasi. Data yang sudah terkumpul dianalisis melalui langkah reduksi data, penyajian data dan verifikasi. Hasil penelitian menunjukan bahwa (1) penerapan pendidikan karakter dalam penggunaan kurikulum 2013 sudah diterapkan secara efektif. Hal ini terlihat dari pengintegrasian pendidikan karakter oleh guru dalam setiap mata pelajaran. (2) dipandang dalam persepekif moral bangsa bahwa karakter yang dimilki siswa terindikasi sudah bermoral bangsa yang baik. Hal ini terbukti dari beberapa karakter yang diterapkan siswa dalam lingkungan sekolah seperti karakter religius, jujur, toleransi, peduli sosial, tanggung jawab, peduli lingkungan, bersahabat dan demokratis. (3) kendala yang dihadapi guru dalam penerapan pendidikan karakter yang utama adalah sarana dan prasarana dan minimnya waktu dalam kegiatan pembelajaran. Ini terlihat dari kurangnya sarana misalnya seperti LCD sebagai penunjang kegiatan pembelajaran dan ketidak tuntasan dalam penyampaian materi pembelajaran.
\end{abstract}

\begin{abstract}
The purpose of this study was to determine the application of character education to the effectiveness of the use of the 2013 curriculum in the nation's moral perspective and to find out the obstacles faced by teachers in the implementation of the 2013 curriculum. The sampling technique using snowball sampling. The key informants in this study were the principal, curriculum committee, homeroom teacher and students. The research data was obtained through observation, interview and documentation techniques. Data that has been collected is analyzed through data reduction steps, data presentation and verification. The results of the study show that (1) the application of character education in the use of the 2013 curriculum has been applied effectively. This can be seen from the integration of character education by teachers in each subject. (2) seen in the nation's moral perspective that the character possessed by students is indicated to have good moral values. This is evident from some of the characters applied by students in the school environment such as religious character, honesty, tolerance, social care, responsibility, caring, friendly and democratic. (3) constraints faced by teachers in implementing the main character education are facilities and infrastructure and the minimum time in learning activities. This can be seen from the lack of facilities such as LCD as supporting learning activities and incompleteness in the delivery of learning material.
\end{abstract}

\section{A. LATAR BELAKANG}

Pendidikan merupakan faktor penting yang sangat menentukan kehidupan manusia untuk meningkatkan kualitas sumber daya manusia. Keberhasilan sebuah pendidikan tidak hanya diukur melalui materi dan kecanggihan teknologi yang digunakan, akan tetapi juga ditentukan oleh keluhuran karakter dan budi pekerti yang luhur. Hal ini dikarenakan dalam dunia pendidikan tidak hanya semata-mata ditentukan oleh kecerdasan intelektual saja akan tetapi diperlukan juga kecerdasan emosi dan sosial.

Undang-Undang No. 20 Tahun 2003 Tentang Sistem Pendidikan Nasional menyatakan bahwa Pendidikan Nasional berfungsi mengembangkan kemampuan dan membentuk watak serta peradaban bangsa yang bermartabat dalam rangka mencerdaskan kehidupan bangsa, bertujuan untuk berkembangnya potensi peserta didik agar menjadi manusia yang beriman dan bertakwa kepada Tuhan Yang Maha Esa, berakhlak mulia, sehat, 
berilmu, cakap, kreatif, mandiri, dan menjadi warga negara yang demokratis serta bertanggungjawab. Penyelenggaraan pendidikan sebagaimana yang diamanatkan dalam Undang-Undang Nomor 20 Tahun 2003 tentang Sistem Pendidikan Nasional diharapkan dapat mewujudkan proses berkembangnya kualitas pribadi peserta didik sebagai generasi penerus bangsa di masa depan.

Kurikulum merupakan sarana untuk mencapai program pendidikan yang dikendaki. Pelaksanaan suatu kurikulum tidak terlepas dari arah perkembangan suatu masyarakat. Perkembangan kurikulum di indonesia pada zaman pasca kemerdekaan hingga saat ini mengalami perubahan sesuai dengan tuntutan zaman serta akan terus mengalami penyempurnaan dalam segi muatan, pelaksanaan, dan evaluasinya. Dalam perjalanan sejarah sejak tahun 1945, kurikulum pendidikan nasional telah mengalami perubahan, dan kurikulum yang dipakai sekarang adalah kurikulum 2013.

Pelajaran serta cara yang digunakan sebagai pedoman penyelenggaraan kegiatan. Dewasa ini bangsa Indonesia dilanda krisis moral, tidak hanya pada tataran pimpinan pemerintahan dan birokrat semata, tetapi telah merambah hingga pada anak-anak sekolah. Hal ini bisa dilihat dari tawuran pelajar, kriminal anak-anak remaja, dan sebagainya. Ini menunjukkan bangsa kita telah kehilangan jati diri dan karakternya. Kemerosotan moral dan memudarnya nilai-nilai kearifan bangsa yang pada zaman dahulu menjadi pondasi bagi keanggunan bangsa Indonesia di mata internasional, sehingga saat ini menjadi kegelisahan semua lapisan masyarakat.

Degradasi moral yang yang telah melanda anak bangsa ini cukup memprihatinkan, hal ini kemudian terlihat jelas dari perilaku-perilaku yang menyimpang dari para siswa. Banyak siswa yang duduk di bangku Sekolah Menengah Atas, melakukan berbagai tindakan yang tidak seharusnya dilakukan oleh mereka yang terdidik dan yang tersadarkan. Hal yang demikian justru jauh berbeda dan jauh dari harapan seperti yang diamanatkan dan dicita-citakan dalam Undang-Undang Nomor 20 Tahun 2003 Tentang Sistem Pendidikan Nasional.

Berdasarkan hasil survei pendahuluan yang dilakukan oleh peneliti di SMA Nurul Jannah NW Ampenan menerangkan bahwa tingkat nilai karakter dalam hubunganya dengan Allah dan karakter hubunganya dengan diri sendiri masih rendah, hal demikin salah satunya dapat dilihat dari beberapa siswa yang kurang toleran terhadap teman dan guru, tidak menaati peraturan, dan kurang bertanggung jawab.

Tujuan penelitian yaitu untuk mengetahui keefektifitasan penerapan pendidikan karakter pada penggunaan kurikulum 2013 pada siswa SMA Nurul Jannah NW Ampenan dan untuk mengetahui kesulitan dan kendala yang dihadapi oleh guru di SMA Nurul Jannah NW Ampenan dalam penerapan kurikulum 2013.

\section{B. METODE PENELITIAN}

1. Metode Penelitian Yang Digunakan

Penelitian ini peneliti menggunakan penelitian kualitatif dengan pendekatan deskriptif, penelitian ini berupaya untuk menjelaskan dan mencoba mendeskripsikan serta mempelajari penerapan pendidikan karakter terhadap efektifitas penggunan kurikulum 2013 dalam persepektif moral bangsa di sekolah SMA Nurul Jannah NW Ampenan

Metode kualitatif sebagai prosedur penelitian yang menghasilkan data deskriptif berupa kata-kata tertulis atau lisan dari orang-orang dan perilaku yang diamati[1]. Penelitian kualitatif adalah metode penelitian yang digunakan untuk meneliti pada kondisi obyek yang alamiah, dimana peneliti adalah sebagai instrumen kunci, teknik pengumpulan data dilakukan secara triangulasi (gabungan), analisis data bersifat induktif, dan hasil penelitian kualitatif lebih menekankan makna [2].

Penelitian deskriptif digunakan untuk berupaya untuk memecahkan atau menjawab permasalahan yang sedang dihadapi pada situasi sekarang. Dilakukan dengan menempuh langkah-langkah pengumpulan, klasifikasi, dan analisis/pengolahan data, membuat kesimpulan dan laporan, dengan tujuan utama untuk membuat gambaran tentang sesuatu keadaan secara objektif dalam suatu deskriptif situasi [3].

Penelitian deskriptif yaitu penelitian yang dilakukan untuk mengetahui gambaran suatu variabel, baik satu variabel atau lebih, tanpa membuat perbandingan, atau menghubungkanya dengan variabel yang lain [4]. Kenapa peneliti mengambil pendekatan deskriptif karena pendekatan deskriptif bertujuan untuk menjelaskan terhadap masalah yang diteliti atau yang terjadi di lapangan, sifat atau kondisi yang sesuai dengan kenyataan.

\section{Lokasi Penelitian}

Penelitian ini dilaksanakan di sekolah SMA Nurul Jannah NW Ampenan Mataram Nusa Tenggara Barat. Mengambil lokasi ini karena dilihat sekolah tersebut telah menerapkan kurikulum 2013.

\section{Penentuan Subyek Penelitian}

Penelitian yang dilakukan ini tergolong penelitian kualitatif, maka subyek penelitian merupakan pihakpihak yang menjadi sasaran peneliti atau sumber yang dapat memberikan informasi. Dalam penelitian kualitatif menggunakan istilah Spradley dinamakan "social situation" atau situasi sosial yan terdiri atas tiga elemen yaitu, tempat (place), pelaku (actor), dan aktivitas (activity) yang berinteraksi secara sinergis [2].

Place adalah tempat, dalam penelitian ini tempat peneliti melakukan penelitian adalah SMA Nurul Jannah NW Ampenan, actor adalah pelaku, pelaku dalam penelitin ini adalah Kepala Sekolah, waka kurikulum, 
wali kelas, guru, dan siswa, activity adalah pendidikan karakter.

Mengenai penentuan subyek penelitian, ada dua teknik dalam pengambilan sampel yaitu probability sampling dan Non-probability sampling. Probability sampling adalah teknik pengambilan sampel yang memberikan peluang yang sama bagi setiap unsur (anggota) populsi untuk dipilih menjdi anggota sampel. Non-probability sampling adalah teknik pengambilan sampel yang tidak memberi peluang/kesempatan sama bagi setiap unsur atau anggota populasi untuk dipilih menjadi sampel.

Berdasarkan pendapat di atas, maka peneliti menggunakan teknik pengambilan sampel dengan cara teknik Non-probability sampling dengan jenis snowball sampling. Hal ini dilakukan karena dari sumber data yang sedikit belum mampu memberikan data yang memuaskan, maka mencari orang lain lagi yang dapat digunakan sebagai sumber data. Dengan demikian jumlah sampel sumber data akan semakin besar.

\section{Teknik Pengumpulan Data}

Teknik pengumpulan data merupakan langkah yang paling startegis dalam penelitian, karena tujuan utama dari penelitian adalah mendapatkan data. Tehnik pengumpulan data adalah cara yang dapat digunakan oleh peneliti untuk mengumpulkan data.

a. Teknik Observasi

Observasi adalah dasar dari segala ilmu pengetahuan. Para ilmuwan hanya dapat bekerja berdasarkan data, yaitu fakta mengenai dunia kenyataan yang diperoleh melalui observasi.

Observasi menjadi observasi berpartisipasi (participant observation), observasi yang secara terus terang atau tersamar (overt observation dan covert observation), dan observasi yang tidak berstruktur (unstruktur observation)[5]. Observasi partisipatif, adalah observasi yang melibatkan peneliti dengan kegiatan sehari-hari orang yang sedang diamati atau yang digunakan sebagai sumber data penelitian. Sementara observasi terus terang atau tersamar, yaitu peneliti dalam melakukan pengumpulan data menyatakan terus terang kepada sumber data, bahwa ia sedang melakukan penelitian. Jadi mereka yang diteliti mengetahui sejak awal sampai akhir tentang aktivitas peneliti. Sedangkan observasi yang tidak berstruktur ialah observasi yang dilakukan dengan tidak berstruktur, karena fokus penelitian belum jelas. Fokus observasi akan berkembang selama kegiatan observasi berlangsung.

Berdasarkan teori di atas, maka dalam penelitian ini peneliti menggunakan jenis observasi yang tidak berstruktur. Terkait dengan penerapan pendidikan karakter terhadap efektifitas penggunan kurikulum 2013 dalam persepektif moral bangsa di SMA Nurul Jannah NW Ampenan.

b. Teknik Wawancara
Wawancara merupakan pertemuan dua orang untuk bertukar informasi dan ide melalui tanya jawab. Wawancara digunakan sebagai teknik pengumpulan data apabila peneliti ingin melakukan study pendahuluan untuk menemukan permasalahan yang harus diteliti, tetapi juga apabila peneliti ingin mengetahui hal-hal dari responden yang lebih mendalam.

Esterberg mengemukakan beberapa macam wawancara, yaitu wawancara terstruktur, semi-struktur, dan tidak terstruktur[6]. Wawancra terstruktur, digunakan sebagai teknik pengumpulan data, bila peneliti atau pengumpul data telah mengetahui dengan pasti tentang informasi apa yang diperoleh. Sementara wanancara semi-struktur, merupakan wawancara yang sudah termasuk dalam kategori in-dept interview, dimana dalam pelaksanaanya lebih bebas bila dibandingkan dengan wawancara terstruktur. Tujuan dari wawancara jenis ini adalah untuk menemukan permasalahan secara lebih terbuka, dimana pihak yang diajak wawancara diminta penadapat, ide-idenya. Sedangkan wawancara tidak terstruktur, adalah wawancara yang bebas dimana peneliti tidak menggunakan pedoman wawancara yang telah tersusun secara sistematis dan lengkap untuk pengumpulan datanya. Pedoman wawancara yang digunakan hanya berupa garis-garis besar permasalahan yang akan ditanyakan.

Mengacu dari pendapat diatas, maka peneliti menggunakan teknik wawancara yang tidak terstruktur. Wawancara tidak terstruktur ini dilakukan secara fece to face dengan mengajukan beberapa pertanyaan kepada responden. Adapun alat-alat yang diperlukan dalam wawancara ini berupa (1) buku catatan, berfungsi untuk mencatat semua percakapan dengan sumber data. (2) tape recorder, berfungsi untuk merekam semua percakapan atau pembicaraan. (3) camera, untuk memotret kalau peneliti sedang melakukan pembicaraan dengan informan/ sumber data.

Peneliti memilih teknik wawancara dengan jenis tidak terstruktur dalam penelitian ini untuk mengetahui sejauh mana penerapan pendidikan karakter terhadap efektifitas penggunaan kurikulum 2013 di SMA Nurul Jannah NW Ampenan dalam persepektif moral bangsa. Sesuai dengan subjek penelitian bahwa wawancara dilakukan kepada empat subjek yaitu Kepala Sekolah, waka kurikulum, guru, dan siswa. Metode ini bermanfaat bagi peneliti karena bisa menggali informasi tentang topik penelitian secara mendalam, bahkan bisa mengungkap hal-hal yang mungkin tidak terpikirkan oleh peneliti itu sendiri.

\section{c. Teknik Dokumentasi}

Dokumen merupakan catatan peristiwa yang sudah berlalu. Dokumen bisa berbentuk tulisan, gambar, atau karya-karya monumental dari seseorang. Dokumen bisa berbentuk tulisan misalnya catatan harian, peraturan, kebujakan dan lain-lain. Dokumen yang berbentuk 
gambar, misalnya foto, gambar hidup, sketsa dan lainlain. Sedangkan dokumen yang berbentuk karya, misalnya karya seni, yang dapat berupa gambar, patung, film dan lain-lain.

Sementara yang akurat berupa, dokumen, bukubuku pelajaran, surat kabar, dan dokumen-dokumen yang lainya. Dengan digunakanya metode ini, saya memperoleh gambar hasil potret bagaimana penerapan pendidikan karakter terhadap efektifitas penggunaan kurikulum 2013 dalam persepektif moral bangsa di SMA Nurul Jannah NW Ampenan. Media ini akan membantu dalam memperoleh data yang akurat, tentang bagaimana penerapan pendidikan karakter terhadap efektifitas penggunaan kurikulum 2013 dalam persepektif moral bangsa.

Manfaat metode ini, peneliti bisa memperoleh hasil dokumentasi dengan memperkuat apa yang telah diwawancara dan diamati. Jadi di sini, tak ada dugaan mengada-ada data ketika disertai dengan wujud nyata penelitian. Metode dokumentasi adalah metode terakhir yang digunakan. Dengan metode ini, peneliti bisa mengkaji penerapan pendidikan karakter terhadap efektifitas penggunaan kurikulum 2013 dalam persepektif moral bangsa di SMA Nurul Jannah NW Ampenan, dengan metode ini dapat memperoleh sesuatu.

\section{Jenis Dan Sumber Data \\ a. Jenis Data}

Jenis data dalam pelaksanaan penelitian dapat dibagi menjadi dua bagian pokok, yakni jenis data kualitatif dan data kuantitatif. Data kualitatif adalah jenis data yang berbentuk kata, kalimat, skema, dan gambar. Sedangkan jenis data kuantitatif adalah data yang berupa angka-angka atau bilangan sesuai dengan bentuknya.

Adapun jenis data yang digunakan dalam penelitian ini adalah data kualitatif bukan data kuantitatif, karena tidak berhubungan dengan angkaangka (statistik), namun dijelaskan dengan kata-kata atau kalimat.

\section{b. Sumber Data}

Bila dilihat dari sumber datanya, maka pengumpula data dapat dilakukan dengan menggunakan sumber data primer dan sumber data sekunder. Sumber data primer adalah sumber data yang langsung memberikan data pada pengumpulan data, sedangkan sumber data sekunder merupakan sumber yang tidak langsung memberikan data kepada pengumpul data, misalnya lewat orang lain atau dokumen (Sugiyono, 2016:225).

Sumber data primer dari penelitian ini adalah wawancara langsung yang dilakukan peneliti dengan responden atau kepala sekolah, waka kurikulum, guru, dan siswa di SMA Nurul Jannah NW Ampenan dari hasil awal yang yang dilakukan. Sedangkan untuk data sekunder diperoleh dari pencatatan dokumen yang ada di SMA Nurul Jannah NW Ampenan maupun informasi yang berhubungan dengan pendidikan karakter. Jadi, dalam penelitian ini akan memakai kedua sumber data yaitu sumber data primer dan sumber data sekunde.

\section{Instrumen Penelitian}

Terdapat dua hal utama yang mempengaruhi kualitas hasil penelitian, yaitu kualitas instrumen penelitian dan kualitas pengumpulan data. Dalam penelitian kualitatif , yang menjadi instrumen atau alat penelitian adalah peneliti itu sendiri. Alasanya ialah, segala sesuatunya belum mempunyai bentuk yang pasti. Masalah, fokus penelitian, prosedur penelitian, hipotesis yang digunakan, bahkan hasil yang diharapkan, itu semuanya tidak dapat ditentukan secara pasti dan jelas sebelumnya. Segala sesuatu masih perlu dikembangkan sepanjang penelitian itu. Dalam keadaan yang serba tidak pasti dan tidak jelas itu, tidak ada pilihan lain dan hanya peneliti itu sendiri sebagai alat satu-satu-satunya yang dapat mencapainya[2].

\section{Tehnik Analisis Data}

Dalam penelitian kualitatif, data diperoleh dari berbagai sumber, dengan menggunakan teknik pengumpulan data yang bermacam-macam (triangulasi), dan dilakukan secara terus-menerus sampai datanya jenuh.

Dengan proses analisis data dalam penelitian kualitatif dan peneliti menggunakan teknik deskriptif, ada tiga komponen dalam analisis data[2] yaitu sebagai berikut:

1. Reduksi data adalah proses merangkum, memilih hal-hal yang pokok, memfokuskan pada -hal yang penting dicari tema dan polanya.

2. Penyajian data adalah merupakan sekumpulan informasi tersusun yang memberikan kemungkinan adanya penarikan kesimpulan dan penarikan tindakan. Dalam penelitian kualitatif, penyajian data bisa dilakukan dalam bentuk uraian singkat, bagan, hubungan antar kategori dan sejenisnya.

3. Verifikasi atau penarikan kesimpulan adalah upaya yang diperoleh selama pengumpulan data berlangsung. Kesimpulan dalam penelitiaan kualitatif merupakan temuan baru yang sebelumnya belum pernah ada.

Metode Pengabsahan Data

Uji keabsahan data dalam penelitian meliputi uji credibility (validitas internal), tranferability (validitas eksternal), dependability (reliabilitas), dan confirmability (obyektifitas).

a) Uji kredibilitas

Uji kredibilitas data atau kepercayaan terhadap data hasil penelitian kualitatif antara lain dilakukan dengan cara perpanjangan pengamatan dan mengadakan membercheck[5].

b) Pengujian Transferability

Transferability merupakan validitas eksternal dalam penelitian kuantitatif. Supaya orang lain dapat memahami hasil penelitian kualitatif sehingga ada 
kemungkinan untuk menerapkan hasil penelitian yanng telah didapat, maka peneliti dalam membuat laporannya harus memberikan uraian yang rinci, jelas, sistematis dan dapat dipercaya[2].

c) Pengujian Dependability

Dalam penelitian kuantitatif, Dependability disebut reliabilitas. Dalam penelitiaan kualitatif, uji Dependability dilakukan dengan melakukan audit terhadap keseluruhan proses penelitian oleh auditor yang indenpenden, atau pembimbing untuk mengaudit keseluruhan aktivitas peneliti dalam melakukan penelitian.

d) Pengujian confirmability

Pengujian confirmaability dalam penelitian kuantitatif disebut dengan uji obyektifitas penelitian. Penelitian dikatakan obyektif bila hasil penelitian telah disepakati banyak orang.

\section{HASIL DAN PEMBAHASAN}

\section{Penerapan Pendidikan Karakter Terhadap} Efektifitas Penggunaan Kurikulum 2013

Kurikulum 2013 lebih ditekankan pada pendidikan karakter, melalaui pengembangan kurikulum 2013 yang berbasis karakter dan berbasis kompetensi diharapkan bangsa ini menjadi bangsa yang bermartabat. Pendidikan karakter dalam kurikulum 2013 bertujuan untuk meningkatkan mutu proses dan hasil pendidikan, yang mengarah pada pembentukan budi pekerti dan akhlak mulia peserta didik.

Penerapan pendidikan karakter di sekolah dalam perencanaan dan pelaksanaanya dilakukan oleh semua Persepektif Moral Bangsa

Kesantunan pribadi seseorang ditentukan oleh baik atau tidaknya moral dalam dirinya. Dalam perkembanganya moral diartikan sebagai kebiasaan dalam bertingkah laku yang baik dan susila. Selanjutnya dalam bahasa Indonesia, kata moral berarti akhlak atau kesusilaan yang mengandung makna tata tertib hati nurani yang membimbing tingkah laku batin dalam hidup.

Moral adalah hal-hal yang berkenaan dengan kesusilaan atau keyakinan tentang aturan-aturan atau ajaran-ajaran yang baik dan buruk, benar dan salah, layak atau tidak layak, patut atau tidak patut. Seorang individu dapat dikatakan baik secara moral apabila bertingkah laku sesuai dengan kaidah-kaidah moral yang ada. Sebaliknya jika perilaku individu itu tidak sesuai dengan kaidah-kaidah yang ada, maka ia akan dikatakan jelek secara moral.

Pendidikan karakter yang merupakan salah satu sarana soft skill yang dapat diintegrasikan dalam pembelajaran pada setiap mata pelajaran. Materi pembelajaran yang berkaitan dengan norma atau nilainilai pada setiap mata pelajaran perlu dikembangkan, dikaitkan dengan konteks kehidupan sehari-hari. Bahkan setiap materi dalam sebuah mata pelajaran perlu diintegrasikan dengan pendidikan karakter. dengan demikian pembelajaran nilai-nilai karakter tidak hanya pada tataran kognitif, tetapi menyentuh pada internalisasi, dan pengamalan nyata dalam kehidupan peserta didik sehari-hari.
Pendidikan karakter perlu diiplementasikan supaya dapat membendung berbagai krisis moral yang terjadi tersebut. Terutama yang terjadi di sekolah. Iplementasi penerapan pendidikan karakter pada siswa di SMA Nurul Jannah NW Ampenan, dari hasil data observasi ditemukan bahwa siswa sudah menerapkan pendidikan karakter dalam lingkungan sekolah secara efektif. Jika dipandang dalam persepektif moral bangsa maka karakter siswa sudah bermoral.

\section{Penerapan Pendidikan Karakter Terhadap}

Efektifitas Penggunaan Kurikulum 2013

Pendidikan merupakan suatu proses pembelajaran yang dilaksanakan secara sistematis oleh pendidik kepada peserta didik. Bahwa penting sekali dalam hal ini setiap anak harus memperoleh hak atas pendidikanya sejak dini, seperti kita ketahui orang tua mendidik anaknya di rumah dengan sebaik-baiknya, tetapi di luar dari pada itu seorang anak juga harus belajar di suatu madrasah atau sekolah yang dapat memberikan pengajaran lebih banyak dan berharga bagi perkembangan anak tersebut.

Pelaksanaan pendidikan karakter yang ada di sekolah pada dasarnya bukan suatu mata pelajaran yang berdiri sendiri, akan tetapi diintegrasikan dalam mata pelajaran. Hal ini sesuai dengan salah satu model pembelajaran pendidikan karakter yaitu memasukkan pendidikan karakter berbasis nilai agama dan budaya bangsa pada setiap mata pelajaran.

Karakter adalah sifat nyata dan berbeda yang ditunjukkan oleh individu, sejumlah atribut yang dapat diamati pada individu. karakter adalah perilaku, akhlak atau budi pekerti yang dimiliki seseorang yang menjadi ciri khas dan membedakanya dengan orang lain[7]. Pendidikan karakter sebagai suatu sistem penanaman nilai-nilai karakter kepada peserta didik yang meliputi komponen: kesadaran, pemahaman, kepedulian, dan komitmen, yang tinggi untuk melaksanakan nilai-nilai tersebut, baik terhadap tuhan yang maha esa, diri sendiri, sesama, lingkungan, maupun masyarakat dan bangsa secara keseluruhan, sehingga menjadi manusia yang sempurna sesuai kodaratnya[8].

Menurunya kualitas moral dalam kehidupan sosial indonesia dewasa ini, terutama di kalangan siswa, menuntut diselenggarakanya pendidikan karakter. sekolah dituntut untuk memainkan peran dan tanggungjawabnya untuk menanamkan dan mengembangkan nilai-nilai yang baik dan membantu para siswa membentuk dan membangun karakter mereka dengan nilai-nilai yang baik.

Dalam pembahasan mengenai Penerapan Pendidikan Karakter Terhadap Efektifitas Penggunaan Kurikulum 2013 Dalam Persepektif Moral Bangsa di SMA Nurul Jannah NW Ampenan ini, dalam pelaksanaanya pendidikan karakter diterapkan tidak secara eksplisit. Maksudnya bahwa pendidikan karakter diterapkan tidak serta merta dapat dilihat oleh kasat mata atau secara langsung, akan tetapi dilakukan secara implisit yakni dengan menginternalisasikan nilai-nilai karakter melalui proses kegiatan belajar mengajar (KBM) dan dengan cara memberikan contoh kepada siswa, pembiasaan yang diterapkan kepada siswa dan mempraktikkanya langsung dalam kehidupan seharihari. Dari hasil wawancara dengan siswa di SMA Nurul Jannah NW Ampenan, di dapat hasil bahwa guru sudah 
cukup baik dalam menerapkan nilai-nilai karakter kepada siswa.

Berdasarkan hasil observasi dan wawancara yang dilakukan peneliti mengenai efektifitas pelaksanaan pendidikan karakter maka ditemukan karakter sebagai berikut:

$\begin{array}{ll}\text { a. } & \text { Nilai karakter Religius } \\ \text { b. } & \text { Nilai Karakter Jujur } \\ \text { c. } & \text { Nilai Karakter Toleransi } \\ \text { d. } & \text { Nilai Karakter Disiplin } \\ \text { e. } & \text { Nilai Karakter Kerja Keras } \\ \text { f. } & \text { Nilai Karakter Kreatif } \\ \text { g. } & \text { Nilai Karakter Mandiri } \\ \text { h. } & \text { Nilai Karakter Demokratis } \\ \text { i. } & \text { Nilai Karakter Rasa Ingin Tahu } \\ \text { j. } & \text { Nilai Karakter Semangat Kebangsaan } \\ \text { k. } & \text { Nilai Karakter Cinta Tanah Air } \\ \text { l. } & \text { Nilai Karakter Menghargai Prestasi } \\ \text { m. } & \text { Nilai Karakter Bersahabat } \\ \text { n. } & \text { Nilai karakter cinta damai } \\ \text { o. } & \text { Nilai Karakter Gemar Membaca } \\ \text { p. } & \text { Nilai Karakter Peduli Lingkungan } \\ \text { q. } & \text { Nilai Karakter Peduli Sosial } \\ \text { r. } & \text { Nilai Karakter Tanggung Jawab }\end{array}$

3. Penerapan Pendidikan Karakter Dalam Persepektif Moral Bangsa

Dalam kajian kebudayaan, nilai merupakan inti dari setiap kebudayaan. Dalam konteks ini, khususnya nilainilai moral yang merupakan sarana pengatur dari kehidupan bersama, sangat menentukan di dalam setiap kebudayaan. Lebih-lebih di era globalisasi yang berada dalam dunia yang terbuka, ikatan nilai-nilai moral mulai melemah. Masyarakat mengalami multikrisis, dan krisis yang dirasakan sangat parah adalah krisis nilai-nilai moral.

Kesantunan pribadi seseorang ditentukan oleh baik atau tidaknya moral dalam dirinya. Seseorang yang menjadikan moral sebagai salah satu ciri khas dalam kepribadianya akan lebih dihargai dan dihormati oleh orang lain atau masyarakat di sekitar tempat tinggalnya. Selain itu, hubungan sosial seseorang yang bermoral akan lebih baik daripada sesorang yang tidak menjunjung moral dalam hidupnya.

Moral pada dasarnya adalah suatu rangkaian nilai dari berbagai macam perilaku yang wajib dipatuhi[9]. Sedangkan menurut Shaffer menjelaskan bahwa moral dapat diartikan sebagai kaidah norma dan pranata yang mampu mengatur perilaku individu dalam menjalani suatu hubungan dengan masyarakat[10].

Berdasarkan hasil wawancara dan observasi yang dilakukan peneliti berkaitan dengan karakter siswa di SMA Nurul Jannah NW Ampenan, dilihat dalam persepektif moral bangsa, iplementasi karakter pada peserta didik sudah cukup baik dan efektif, yang artinya karakter yang dimiliki siswa di SMA Nurul Jannah telah terindikasi bermoral

\section{SIMPULAN DAN SARAN}

Simpulan dalam artikel ini menjelaskan beberapa hal yaitu 1) Penerapan pendidikan karakter dalam penggunaan kurikulum 2013 di SMA Nurul Jannah NW Ampenan, sudah diintegrasikan diterapkan pada semua mata pelajaran. Penerapan pendidikan karakter diterapkan melalui dua proses yaitu melalui kegiatan pembelajaran dan kegiatan di luar pembelajaran. Dari yang demikian itu maka penerapan pendidikan karakter dalam penggunaan kurikulum 2013 sudah diterapkan secara efektif. 2) Penerapan Pendidikan Karakter Dalam Persepektif Moral Bangsa sudah sesuai implementasi 18 nilai dalam pendidikan karakter pada siswa di SMA Nurul Jannah NW Ampenan telah teriplementasi dengan baik dan karakter yang dimiliki siswa terindikasi pada moral bangsa atau karakter bangsa yang baik. 3) Kesulitan dan Kendala Yang Dihadapi Guru Dalam Penerapan Kurikulum 2013 adalah masalah sarana dan prasarana sebagai penunjang kegiatan belajar mengajar (KBM), dan keterbatasan waktu dalam kegiatan pembelajaran.

Saran yang berguna bagi peningkatan pelaksanaan pendidikan karakter di SMA Nurul Jannah NW Ampenan, diantaranya: 1) Pihak sekolah diharapkan dapat mengupayakan peningkatan pemahaman orang tua siswa terhadap pendidikan karakter terutama di lingkungan keluarga, karena mengingat kontrol sekolah yang terbatas. Hal ini dapat dilakukan dengan meningkatkan peran orang tua dalam pendidikan karakter, baik di lingkungan keluarga maupun masyarakat. Sehingga diharapkan peserta didik dapat memiliki karakter yang baik. 2) Perlunya dukungan, perhatian dan pengawasan dari orang tua dalam pembentukan karakter peserta didik. Karena pendidikan karakter bukan hanya tanggung jawab sekolah semata, melainkan tanggung jawab bersama agar apa yang diterapkan di sekolah bisa sejalan dengan lingkungan keluarga dan tempat tinggal. 3) Meskipun pembinan karakter sudah memberikan perubahan yang positif, pihak sekolah maupun guru harus senantiasa melaksanakan kegiatan-kegiatan yang akan mengembangkan karakter siswa secara continue agar karakter yang sudah terbentuk pada anak tidak akan hilang. 4) Kepada siswa SMA Nurul Jannah NW Ampenan sebagai generasi yang akan datang, peneliti menyarankan agar terus menerapkan sikap dan karakter dengan sungguh-sungguh.

\section{UCAPAN TERIMA KASIH}

Penulis mengucapkan terima kasih kepada editor yang senantiasa memberikan saran dan masukan kepada penulis sehingga artikel ilimiah ini selesai dengan baik.

\section{DAFTAR RUJUKAN}

[1] L. J. Moleong, Metodologi penelitian. 1999.

[2] P. Sugiyono, Metode Penelitian Kuantitatif, Kualitatif, dan $R \& D .2013$.

[3] H. P. Setyosari, Metode penelitian pendidikan \& pengembangan. Prenada Media, 2016.

[4] M. Abdurrahman and S. A. Muhidin, "Panduan Praktis Memahami Penelitian," Bandung CV. Pustaka Setia, 2011.

[5] P. Sugiyono, "Dr. 2010," Metod. Penelit. Kuantitatif, Kualitatif, dan R\&D. Bandung CV Alf.

[6] K. G. Esterberg, "Qualitative methods in social research," 
2002.

[7] M. F. Hidayatullah and M. Rohmadi, Pendidikan karakter: membangun peradaban bangsa. Yuma Pustaka, 2010.

[8] E. Mulyasa, "Manajemen dan kepemimpinan kepala sekolah," Jakarta Bumi Aksara, 2012.

[9] N. Y. Gunarsa, "Singgih D., dan Singgih D Gunarsa," Psikol. Keluarga, Jakarta BPK Gunung Mulia, 1986.

[10] M. T. Ilahi and R. K. Ratri, Revitalisasi Pendidikan Berbasis Moral. Ar-Ruzz Media, 2012. 